\title{
The Innovated Writing Process (IWP) Approach: a Practical Bridge between Recent SLA and Applied Linguistics Theories
}

\author{
Anwar Mourssi (Corresponding author) \\ Faculty of Arts, Creative Industrial and Education, University of the West of England, Bristol, UK \\ $\&$ \\ Higher College of Technology, Muscat \\ P. O Box 546, P. C. 115, the Sultanate of Oman
}

Tel: 968-9975-2788_E-mail: anwarmohd1967@yahoo.com, anwar.mourssi@hct.edu.om

Received: November 17, 2012

doi:10.5430/elr.v1n2p102
Accepted: December 10, $2012 \quad$ Published: December 11, 2012

URL: http://dx.doi.org/10.5430/elr.v1n2p102

\begin{abstract}
Based on the shortcomings found in previous methods of teaching writing and following recent works in applied linguistics and second language acquisition on form-focused instruction, explicit teaching and learning, and types of feedback, the Innovated Writing Process (IWP) approach was designed. This is one of the findings of an empirical study in the context of Arab learners of English (ALEs) in the Sultanate of Oman. It is also an attempt to apply Sociocultural Theory in classroom settings and to show how input can be well-processed which, in turn, can develop the second language (L2) learners' internalized grammatical system. The method used in this study indicates that metalinguistic feedback- one form of interaction between the instructor and learners - may be one of the most successful feedback types in helping L2 learners acquire second language linguistic items.

Keywords: Innovated Writing Process, IWP, Metalinguistic feedback, Interaction, Negotiation and SLA

\section{Introduction}

The IWP approach is primarily based on the definition of method as it is essentially the level at which theory is put into practice and at which choices are made about particular skills, content and the order of which the content is presented. The IWP approach is therefore defined as a suggested method of teaching writing which involves both speaking and writing processes based on the learners' level. It aims at improving learners' accuracy as well as fluency. It is based on a full study on a sample of Arab Learners of English (ALEs).

One of the assumptions suggests that the implementation of the IWP approach on ALEs would help learners improve their writing and speaking skills. What distinguish the IWP approachare the procedures and tasks involved while teaching writing. These procedures and tasks include: the process of contrastive analysis and error analysis based on the sample mistakes; explicit grammar teaching; negotiation of meaning and form based on the sample level of interlanguage grammar; interaction between teacher-students and students-students in a form of communicative grammar language teaching; and finally, metalinguistic feedback, whether direct or indirect, based on the nature of the learners' errors/mistakes.
\end{abstract}

\subsection{Rationale for the Design of the IWP approach}

As the author analyzedinterlanguage grammar in L2 and contrasted the errors which appear to originate in L1 and L2 linguistic items, he discovered that this contrastive analysis shed considerable light on errors related to forming the simple past regular and irregular verbs e.g. to wented, was went. He thought that there should be a method which could be implemented to narrow the gap between the L1 and the L2 learners' internalized grammar system and which would take into consideration the significant differences between Arabic and English language. The researcher thought that this might be achieved by increasing the role of the teacher's interactions and instructions while concentrating on analyzing L2 learners'interlanguage grammar.The explanation and analysis of the learners' non-target-like forms should be performed using explicit grammar learning following Meaning negotiation and Form negotiation when necessary and using metalinguistic feedback (here defined as: explaining the nature of the learners' mistakes without providing the target-like forms). Implementing these stages might motivate L2 learners and give them the opportunity to revise and redraft their writing- most of learners feel that writing activity is a boring task and they do not wishto have to revise and redraft it as well- to develop their internalized grammar which will be reflected 
in their writing. After implementing the IWP with the subjects of the empirical study for a period of about four months, the researcher concluded that explicit grammar learning with teacher's instructionsand interactions alongsidemetalinguistic feedback and L2 learners' communication with each other and with the teacher, might be more effective and more useful for acquiring the simple past tense forms in English (or any other linguistic data). This in turn, would result in improving the second language learners' internalized grammatical system.

\subsection{Background of the IWP approach}

It is a known fact that the English Language has been present as a core subject in the general education schools in most of the Arab countries since the 1950s. The methods used in English Language teaching at that time were mainly rote learning - memorisation - and grammar translation methods. Between 1980s and 1990s, there was a change in the English Syllabus. The emphasis was to be placed on the four skills of listening, speaking, reading and writing. Nevertheless, the traditional methods of English teaching are still widely used in teaching of certain skills.

Based on many years' experience of teaching English to ALEs, itis clear to the researcher that writing was not considered as a skill which should be taught in the classroom. The reason for this was the fact that the emphasis was on teaching grammar, extensivevocabulary and reading. This method was followed by adapting Product/Guided Writing method in the 1990s, where foreign language learners were taught short phrases/phrasal verbs and were asked to form sentences and short paragraphs by adding a subject or an object to the parts of speech given. There was no oral/written or direct/indirect/metalinguistic feedback given by the teacher. Marking was based on ticking and very short comments (Seen/Good/Well done/Bad or Thank you).

In commenting on the birth of process writing in the 1990s, Hedge (2003) mentions that in the 1990s the methodology of teaching writing in ELT classrooms made dramatic departure from traditional approaches and she designed seven stages of process writing (p.300), while Richards, Platt \& Weber (1999) define process writing as an approach which emphasizes the composing process where the writer makes use of tools such as planning, drafting and revising (p.290). On the other hand Atwell (1987) introduces "a five step system of writing process" prewriting/ drafting/ revising / editing/and publishing (p.3). In real context, Pennington, Brock \&Yue (1996) conducted a study based on two groups. The first practised process writing and the second practised traditional language exercises and grammatical accuracy with very little integration of elements of process writing. The first group achieved higher progress in writing.

In an evaluation of adopting and adapting process writing in the 2000s, Ferris (2002, 2003, and 2004) and Bitchener (2005) point out that in recent years there has been an increasing awareness amongst L2 writing researchers and teachers that classroom-based instruction can play a significant role in helping L2 learners improve the accuracy of their writing texts.

Mourssi (2006), in his MA dissertation concluded that motivation and learning strategies can play a remarkable role in improving foreign language learners' writing. The emphasis was on the role of three main elements inside the classroom, namely: teacher/ learner/ the course book, as well as three sub-elements outside the classroom, namely: school/ home/ and society.

Each method and approach has its own theory of language and theory of language learning. In what follows, the theory of language on which the IWP approach is basedwill be discussed.

\section{Theories of Language and Language Learning in the IWPApproach}

\subsection{Theory of Language in the IWP Approach}

The IWPapproach is based on integrating three different theoretical views of language. The first one is thestructural view where language is considered as a system of structurally related elements for the coding of meaning. The mastery of these elements in this system is the target of language learning. The elements of this system are defined as: phonological units, grammatical units, grammatical operations and lexical items.

The second view is the functional view where language is viewed as a vehicle for the expression of functional meaning, and where the emphasis is on semantic and communicative dimension rather than on grammatical characteristics of language teaching content by categories of meaning and function rather than elements of grammar and structure.

The third view is the interactional view where language is seen as a tool for the creation and maintenance of social relations. This view has been added since "interaction" has been central to theories of second/foreign language learning and pedagogy for more than thirty years, when Rivers (1987) defines the interactive perspective in language education: 
"Students achieve facility in using a language when their attention is focused on conveying and receiving authentic messages that contain information of interest to both speaker and listener in a situation of importance to both" (p.4).

In other words, the IWP approach can represent implications of the Sociocultural Theory in SLA.

\subsection{Theory of Language Learning in the IWP Approach}

In general, the IWP approach is derived from adapting three common and well known theories in the field of SLA, aiming at changing the theoretical frameworks of these theories into a pedagogical framework to be implemented and activated inside the classroom context. In particular, the IWP approach is based on integrating three well known theoretical approaches in explaining second language learning namely: Behaviourism, Innatism, and Interactionism, which reflect the theory of language of the IWP approach.

In detail, Behaviourismstates that language learning is the result of imitation, practice and feedback, while Innatism gives priority to learners' innate characteristics (which Chomsky calls "Innatism Position"), and Interactionism focuses on the role the linguistic environment in interaction with the learner's innate capacities.

To be more specific, theory of language learning in the IWP approachmatches with the Behaviourism theory which believes that learners receive linguistic input from speakers in their environment and which also outlines that language learners start off with the habits formed in L1 as they linked the second language learning with Contrastive Analysis Hypothesis (CAH). CAH claims that when there are similarities between L1 and L2, the learners will acquire the Target Language with ease, but when there are differences, the learners will have more difficulties (Cook, 2001). This is what happens with Arab Learners of English due to significant differences between Arabic and English, and the crosslinguistic influence of L1 in the acquisition of L2 is indicated in the current empirical study. From this point, one part of the teacher's and of the learners' role is formed in the IWP approach.

The second theory on which the IWP approach is based is Innatism, which states that language learning is based on L1 acquisition not L2 acquisition, and that the Universal Grammar (UG) is based on language competence in the target language. According to the IWP approach the UG should be available to second/foreign language learners and at the same time language competence should not be practical without language performance in which foreign/second language learners transform their knowledge of the language into use of the language. Other linguists termed these changes as changing the declarative knowledge that into procedural knowledge how through practice (Anderson (1995) and DeKeyser $(1998,2003)$. In other words, the IWP approach is basically associated with the kind of learning which takes place in the classroom environment, where ruleslearning must be followed by practice, and when practice is not enough to get reasonable output, input should be reprocessed to be more understandable and more comprehensibleuntil such time when the learners become able to use the target rules. From this point, another part of the teacher's and of the learners' role in the IWP approach is formed. Pica (2008) concludes that the more time is spent in treating the form, the more form is retained in learners' mind.

The third theory on which the IWP approach is based is the Interactionism. This theory is based on the first two theories mentioned above where the first one states that learning is based on receiving the linguistic input from the speakers in the learners' environment, while the second one states that learning is based on increasing the comprehensive input. The researcher thinks that these two theories cannot be performed or implemented without interaction. The interaction comes in the form of negotiationwhich will not concentrate on one aspect only whilst ignoring the other, but it will be negotiation of both form and meaning in the form of metalinguistic feedback following the processes of error analysis and contrastive analysis based on the type of learners' errors/mistakes.

Gass\&Selinker (2008) claim that the interaction approach accounts through input exposure to language, production of language output, and feedback that comes as a result of interaction. They add that negotiation, recasts and feedback are items that involve in interaction. They also add that negotiation serves as catalyst for change because of its focus on non-target-like forms, by providing learners with information about non-target-like forms; negotiation enables learners to search for additional confirmatory evidence (p.331). The negotiation is termed in the current method as metalinguistic feedback.

The target and the theory of language learning of the IWP approach in teaching writing do not stop here. The method insists on the fact that the previous concepts and theoretical procedures will not become useful in the practical aspects inside the classroom without giving space and opportunities to the language learners to participate, speak, interact, ask and argue with other speakers-teacher and students- inside the classroom. This leads us to the essential role of Contrastive Analysis which the teacher should follow in explaining learners' errors related to L1 and the basic role of the process of Error Analysis which the teacher should follow in explaining learners' errors related to L2.All 
these procedures appear in the suggested method of Communicative Grammar Language Teaching Approach CGLTA and in the updated method of explicit grammar teaching/learning in the IWP approach.

The above procedures show and emphasize the importance of corrective feedback, specifically metalinguistic feedback which, when it is implemented correctly, is seen as an opportunity for language learners to develop theirinterlanguage grammar and internalized grammar system. This supports Long's theory (1996) that these procedures in turn give language learners opportunities to produce reasonable output which results in pushing learners ahead in their development (Swain, 1985).

In conclusion, the theory of language learning in the IWP approach includes both process-oriented theories which are built on learning process, and condition-oriented theorieswhich emphasizes the nature of learners and the environment where language learning takes place. We as researchers, have to have in mind the principle that to predict or to analyze the learners' errors may provide the teacher and the learners with many opportunities to interact, negotiate, and with valuable information in the areas of difficulties that learners may encounter. This might help learners develop their interlanguage grammar and, in turn, help them develop their internalized grammatical system. What links theory with practice or approach/method with procedures is what is called "Design". In what follows the design of the IWP method is discussed.

\section{The Design of the IWP Approach}

The design of the IWP approach includes: the objectives of the method, the content of the method, the syllabus, followed by the role of the teacher and the learners, and finally the role of the instructional materials.

\subsection{The Objectives of the IWP Approach}

As the IWP approach is based on process-oriented theories and condition-oriented theories, the objectives of the IWP approach are linguistically oriented, having in consideration the nature of the ALEs and the educational environment where language learning takes place. The objectives of the IWP approach are as follows:

- to improve learners' accuracy and fluency reflected in improving their speaking as well as writing;

- to present explicit grammar in a stimulating and motivating way using suitable teaching materials which attract the learners attention, e.g. picture-story writing;

- to increase awareness of contrastive aspects between L1 and L2 and to internalize these features as part of their L2 grammar;

- to transfer the explicit knowledge to learners' speaking abilities as well as their written work;

- to teach students how to notice their mistakes by interacting while speaking as well as writing.

Sets of picture-story writing can be selected as the basis on which the students are asked to write an essay; these writing tasks should be related to the learners' environment. These tasks could be designated as the teaching materials. The researcher designed the teaching plan (see Appendix A) following his suggested method of teaching writing, namely, the Innovative Writing Process approach. The experiment lasted four months (16 weeks).

\subsection{The Content of the IWP Approach}

The IWP approachconsists of seven main stages which involve the speaking process as well as the writing process. In what follows the stages of the suggested framework of the innovated writing process are described.

\subsubsection{The Main Seven Stages in the IWPApproach}

\subsubsection{Stage One (Discussion)}

This stage includes open discussion inside the classroom; it can be in the form of small groups of four students or in pairs. The discussion is followed by brainstorming and making notes in addition to asking questions and suggesting ideas and sequences related to the target topic. The most important factor here is that the teacher should motivate all the students to participate in the activity/task; however, he/she should organize/control the discussion in order to avoid the drawbacks of the communicative approach (one of the drawbacks of Communicative approach is giving the opportunity to the learners to talk without control or correcting their mistakes).

\subsubsection{Stage Two (Oral Feedback on Discussion and Analyzing Spoken Mistakes)}

The teacher's role here is to render oral feedback on the speaking abilities of the students, explaining the mistakes that students madewhile speaking. The teacher starts analyzing the mistakes on the board following the Grammar Translation Method. The students are then asked to speak again about the same topic paying attention to the mistakes they had made previously. The teacher can interrupt students if they make the same mistakes in order to give his/her 
metalinguistic feedback on the non-target-like forms following the procedures of Communicative Language Teaching method (CLT) and Task-Based approach (TB). Although CLT and TB do not generally focus on mistakes, they might suggest ways in which mistakes can be highlighted and corrected through repetition and correction.

\subsubsection{Stage Three (Planning)}

Students are to select ideas individually, arrange the information and structure the text, followed by self-evaluation and participation in group-evaluation while planning the initial draft. The teacher's role is to give his/her oral/written feedback on planning for each group depending on the learners' output.

\subsubsection{Stage Four (First Draft)}

Following the first three stages, students are asked to write the first draft asking the teacher for help when it is required. If they are not able to finish the first draft during class time, they are allowed to complete it when after school. The teacher should ask students not to get help from others in performing this task: the first draft must be written by students themselves in order to find out what the gaps are.

\subsubsection{Stage Five (Oral/Written Feedback on the First Draft)}

The teacher asks students to have group/peer evaluation. The role of the teacher at this point is to give his/her general written feedback, based on the students' writing following the procedures and carrying out the role of the teacher and the role of the learners while performing the Task-Based approach in explaining and correcting the mistakes (Nunan, 2009, p. 66-67). It is suggested that oral feedback may be better in which the teacher presents the metalinguistic feedback for all the students, however, some students prefer to get written feedback. It is the role of the teacher to keep the individual differences in mind.

\subsubsection{Stage Six (Analyzing Written Mistakes and Writing up Second Draft)}

After providing the feedback on the first draft, the teacher presents and explains the written mistakes on the board to all the students. Thestudents are then asked to write their second draft based on the previous input they have already gained from the previous stages. This stage is an attempt to re-process the input for low/high level learners.

\subsubsection{Stage Seven (Final Written and Spoken Draft)}

If the students still make mistakes in their writing, the teacher should hold individual discussionsduring which he/she explains the mistakesto weaker student/s individually. After all students finish their final draft, they are asked to read their writing to all students. The teacher should ask students to comment on each piece of writing in a communicative and confident way. The researcher thinks that including the audience who are to listen to the speaker student in evaluation might motivate the ALEs to get more interest in interacting with the teacher and in turn to revise and redraft their writing whenever they feel they need to. Here they become aware of what they do and feel that they have to spend more time revising and redrafting their writing in order to produce a good piece of writing.

In what follows the learners' different settings in the IWP approach, the theories of SLA and proposals used in implementing the IWP approach and finally the integrated ELT methods and approaches followed in the IWP approach are discussed.

\subsubsection{Learners' Settings in the IWP Approach}

To discuss the learners' settings in the IWP approach, first it needs to be agreed that learning foreign/second language naturally is different from instructionally learned languages. In other words, learning from natural situations is different from learning in a classroom; and therefore, acquiring is different from learning with respect to Krashen's(1982) classification. Based on the drawbacks of different situations and different learning settings, the IWP approach exemplifies the advantages of the three different settings inside the classroom, aiming at creating a variety of settings to cover the different attitudes and the individual differences of the students inside the classroom. These settings are: natural setting, instructional setting and finally the communicative setting. In what follows the characteristics of each setting are described, see Figure 1.

\subsubsection{Natural Setting}

This is the first setting followed in the IWP approach, where learners have their freedom to interact as if they were outside of the classroom. They should feel free to interact with each other. Following this setting, they will be exposed to a variety of vocabulary and structures. Each learner should interact using the foreign language to their best ability.The main goal of this setting is to improve learners' fluency and get rid of any anxiety. 


\subsubsection{Structure - Based Instructional Setting}

In this setting, learners learn linguistic items one by one. The teacher presents the simple ones followed by more difficult ones. The learners' errors must be analyzedin order to improve their accuracy. To be more practical, the teacher asks questions which students answer, the teacher then evaluates the learners' answers - this is called Initiation/ Response/ Evaluations (IRE) exchange (Lightbown\&Spada, 2006, p. 112). This setting is essential in terms of the teacher's analysis of learners' errors following ex-implicit grammar teaching and giving the corrective feedback in the form of recast feedback, metalinguistic feedback and finally elicitation feedback. The weaker learners get the opportunity to participate actively in the writing task.

\subsubsection{Communicative Instructional Setting}

The third setting is a result of the first two settings, which both aim at improving learners' fluency and accuracy. The third setting aims at re-processing the input to be more comprehensive and understandable. It is considered to be the most important for learners in order to get the chance to interacteffectively, correct their errors, arrange their ideas and produce appropriate piece of writing based on the outcome of the previous two settings. In this setting, the teacher focuses on meaning negotiation havingensured that learners have learnt the target structures related to the task in the previous settings.

\subsubsection{Theories of SLA and Proposals Implemented in the IWP Approach}

The four proposals in the IWP approach see Figure 2, have been suggested in order to develop and implement SLA theories inside the classroom. These four proposals match with the learners' settings mentioned previously and with the ELT methods and approaches which will be discussedlater on. The four proposals are:

\subsubsection{Let's Talk}

This proposal emphasises the importance of access to both comprehensible input and conversational interactions between the teacher and the learners (Lightbown\&Spada, 2006, p. 150).

\subsubsection{Get It Right from the Beginning}

This proposal is selected because of the nature of the ALEs whose previous language learning experience was in grammar translation classes. Lightbown \& Spada (2006) claim that teachers avoid giving opportunities for learners to speak freely because this would allow them to make errors (p.139). It is therefore better to give feedback directly and give the chance for learners to produce target-like language from the beginning. This will help learners to makefewer errors while using the language.

\subsubsection{Teach What is Teachable}

This proposal is the practical interpretation of Pienemann's (2005) developmental features and processability theory explaining that some things can be taught successfully whereas other things seem to remain un-acquired. In other words, teachers should realize the stages through which learners may pass in learning linguistic items. It will be useless to try to teach a forward stage before a previous one, so in the IWP approach teachers should start with what is teachable and what is learnable first.

\subsubsection{Get It Right in the End}

This proposal is suggested in order to practically interpret both theories of SLA, namely: Form-Focused Instruction (FFI) and Meaning-Focused Instruction (MFI)as well as their importance in the IWP approach. It is also proposed in order to ensure and agree with the previous proposal "Teach what is teachable" which states that if teaching fails to take the learners' readiness into account, some things cannot be taught. This proposal also emphasizes that some aspects of language must be taught explicitly (Lightbown\&Spada, 2006, p.166).

\subsubsection{The ELT Methods and Approaches Followed in the IWP Approach}

In general, the IWP approach is designed to be followed and implemented in teaching writing; it aims at improving learners' fluency and accuracy. The IWP approach is the main outcome and the basic finding concluded from my own empirical study (Mourssi, 2012a). Therefore, the IWP approach is based on a systematic integration of four well known and common ELT approaches, see Figure 3.

\subsubsection{Audio-Lingual Approach}

In the Audio-Lingual approach,following the opportunity for the learners to interact in the form of dialogues, specific grammatical patterns in the dialogues are selected based on the pictures provided and become the focus of various kinds of drill and pattern-practice exercises (Richards \& Rodgers, 2006, p. 59). This supports Lightbown and 
Spada's (2006) theory which states that in Audio-Lingual approach there is little use of the first language, and learners are expected to learn mainly through repetition and habit formation: Audiolingualism is based on communicative approach where implicit learning is used (p.112).

\subsubsection{Grammar-Translation Method (GTM)}

The second method is the Grammar Translation Method (GTM). It integrates performing certain stages in the IWP method in explaining learners' errors. Themain principle of the GTM is that the sentence is the basic unit of teaching and language practice. Richards \& Rodgers (2006) mention that GTM is still widely practised; it has no advocates although it is a method for which there is no theory (p.7). While implementing the IWP method with ALEs, it is concluded that ALEs become highly motivated and participate effectively while following the GTM in analyzing and correcting their errors as GTM is based on grammar rules where explicit grammar learning is used.

\subsubsection{Communicative Language Teaching Approach (CLT)}

The third approach is communicative Language Teaching approach (CLT). It is integrated with the previous approaches based on the characteristics of communicative view of language which has theoretical base: where language is thought as a system for the expression of meaning, the basic and primary function of language is to allow interaction and communication, and finally the structure of language reflects its functional and communicative uses (Richards \&Rodgers, 2006, p. 161).These concepts are implemented and performed in the IWP approach following the suggested stages one by one shifting between the different methods mentioned above. Having in consideration communicative approach, it is proposed that learning a language can be through implicit and explicit learning.

\subsubsection{Task-Based Approach}

The last approach which comes at the end of the IWP approach is Task-Based Language Teaching (TBLT). The TBLT is selected to be integrated in performing the IWP approach, based on its assumptions assumed by Feez (1998, p. 17). Some of the assumptions are: the focus of the TBLT is on the process rather than product; the activities and tasks can be either those which learners might need to achieve in real life or those which have a specific pedagogical purpose, and finally the taught activities are sequenced according to the degree of difficulty and the previous experience of the learners, beside the complexity of the task, and finally the language required to undertake the task.

\subsection{The Syllabus of the IWP Approach}

The IWP method has no specific syllabus since it is a process-based method. Richards \& Rodgers (2006) mention that term syllabus is less frequently used in process-based methods, in which consideration of language content are often secondary (p.26). However, the teacher's activities and the learners' activities can be formed as follows:

\subsubsection{The Teacher's Activities}

The teacher motivates, presents, evaluates, explains, and analyzes the errors, giving oral, written, direct feedback (giving the target-like form), indirect feedback (using recasting for example), and metalinguistic feedback in which the teacher explains the nature of the mistakes without providing the target-like forms for the learners.

\subsubsection{The Learners' Tasks}

Students revise and redraft their speaking in a speaking process (having spacefrom the teacher to prepare and reformulate their speech before answering the target task) as well as writing in a writing process, notice their mistakes and interact with the teacher to fill in the gaps in their knowledge of $\mathrm{L} 2$.

\subsection{The Roles of the Teacher and the Roles of the Learners in the IWPApproach}

The role of the teacher and the role of the learners in the IWPapproachare presented in Table 1.

\subsection{The Role of Instructional Materials}

Picture-story is one of the main forms of teaching materials in the IWP approachfor the following reasons:

- pictures can motivate the students to pay attention;

- $\quad$ pictures can motivate the students to take part in the story;

- pictures can contribute to the context in which the language is being used;

- $\quad$ pictures can bring the outside world into the classroom;

- $\quad$ pictures can be used in many different ways;

- $\quad$ pictures can cue responses to questions; 
- $\quad$ pictures can cue substitutions through controlled practice;

- $\quad$ ictures can provide information to be referred to in conversation and discussion (which serve improving speaking as well as writing).

Where the teacher is a stimulator/ pictures will be stimulating/ learners will be stimulated / teaching writing will be a kind of stimulation which tame and persuade learners to participate efficiently. However, the teacher can apply the IWP approach to other types of writing, e.g. general/academic writing.

\section{The Procedures of the IWP Approach}

The Procedures Focus on Presenting, Practice and Feedback (PPF)

\subsection{Presenting}

The teacher presents the target linguistic datathrough the task, e.g. the simple past tense forms is better presented by the picture-story writing.

\subsection{Practice}

Students practise speaking process and writing process following revising and redrafting in performing the task.

\subsection{Feedback}

Teacher follows the process of error analysis as well as contrastive analysis process by implementing the different types of feedback based on the type of the non-target-like forms produced and the level of the learners.

\section{The Linguistics Characteristics Found by Implementing the IWPApproach}

- Students realized the differences between L1 and L2. They learned that English sentences must start with a subject and not, as Arabic sentences, with a verb.

- Students learned that they cannot over-generalize the role of others e.g. adding $-d$, or $-e d$ to all verbs in forming a target-like English simple past sentence.

- $\quad$ Students learned how to practise process speaking as well as process writing following the suggested stages in IWP while noticing their mistakes and interacting.

- Students learned the differences between the tenses in the English language which are different from tenses in Arabic, e.g. when they use simple past and when they use past continuous tense.

6. Evaluation and Implementation of the IWP Approach as a Practical Bridge between Recent SLA and Applied Linguistics Theories

The current method argues that learning occurs when there is explicit grammar teaching and student-student, student-teacher and teacher-student interaction. Students make successive hypotheses about forms and these are discussed in "negotiated interaction" which is based on negotiating the mistakes and creating a space for that to happen, following the process of error/contrastive analysis in which the teacher discusses the errors explaining their nature (metalinguistic feedback). This section evaluates the theoretical underpinnings which support this approach. 6.1 presents the rationale for Form-Focused Instruction, with a sub-section dealing with corrective feedback in 6.1.1; 6.2 recapitulates the arguments for Interactional Methods which are outlined in Sociocultural Theory. Finally, 6.3 presents Autonomous Induction Theory which highlights that learning results from a coalition of resourcesand not from a single specific one.

\subsection{Form-Focused Instruction}

The IWP approachwas designed as a programme for teaching writing, and was implemented in the classroom settings to investigate the impact of Revising and Redrafting on improving ALEs' written accuracy. The IWP approach focuses on the role of both the teacher and the learner and gives detailed guidelines for instructors to follow. In designing the IWP, a variety of teaching methods were integrated bearing in mind the L2 learners' level and the types of error/mistake which emerge as they prepare their written work. Corrective feedback is provided to the learners by analyzing their errors/mistakes and explaining the nature of the errors/mistakes produced during writing,and how L2 learners produce the target-like forms themselves following metalinguistic feedback. One clear aspect of the course is Form-Focused Instruction (FFI).

Norris \& Ortega (2001), in Fotos\&Nassaji (2007, p. 11) postulate that FFI produces substantial gains in terms of the acquisition of the target structure. Over the course of their study, the effects of FFI were observed to have been sustained over time and the study showed that explicit instructional techniques yielded more positive effects than 
those involving implicit techniques. Thus, the effectiveness of the instructional treatments depends on the methodological approaches adopted. In evaluating the tasks achieved following FFI, Fotos\&Ellis(1991), Fotos (1993), and Leow (2001) noticed that some of the FFI tasks were incorporated more explicitly and that "raising grammar consciousness" is one of these tasks, whereby, the task objective given to learners is to solve a grammar problem using the target structure or to generate grammar rules. That is, the aim behind not giving the target-like forms directly to the L2 learners, but providing them with corrective feedback and allowing them to analyze their errors/mistakes is that it gives them the space to interact, negotiate and work out the rules for themselves which makes them more memorable. Both Lyster (2004) and Ferris (2006) suggest that corrective feedback prods the learners to self-correct and that this is effective in promoting SLA.

\subsubsection{The Efficacy of Analyzing L2 Learners' Errors/Mistakes in SLA Through the IWPApproach}

The efficacy of analyzing L2 learners' errors/mistakes and giving corrective feedback in language pedagogy varies according to the methods used during the learning process. For example, Audiolingualism states that negative "assessment" is to be avoided as far as possible since corrective feedback functions as "punishment" and may inhibit or discourage learning, while Ur (1996) suggests that "assessment should be positive" in order to promote the positive self-image of the learner as a person and language learner," (p. 243).On the other hand, skill-learning theory states that "the learner needs feedback on how well he/she is doing," but the question here is what kind of feedback is the most effective? Is it direct, indirect or metalinguistic feedback? In designing the IWPapproach, all three types were implemented but the last type (metalinguistic feedback) was the basic type followed with the subjects of the study. It was indicated that metalinguistic feedback can well work in SLA.

Ur (1996) recognizes that there is certainly a space for correcting learners' errors/mistakes, but she claimed that this contribution should not be over-estimated. She concluded that time should be invested in avoiding errors rather than in correcting them. Other methodologists, for example, Harmer (1991) distinguished between "accuracy" and "fluency". Harmer mentions that corrective feedback has a place in the former but not in the latter. However, SLA researchers, especially those working within an Interactionist framework take a different view; they argue that corrective feedback works best when it occurs in context at the time the learners make the error. I can claim that this is one of the main aims behind designing the IWP approachand presenting the CGLTA through the IWP in the ALEs' context, where the process of error/contrastive analysis (metalinguistic feedback) can develop L2 learners' internalized grammar system which results in promoting L2 grammar acquisition and improving learners' written accuracy.

With the IWPapproach, every stage of the development is built following a previous one. In investigating the role of the learner and the role of the teacher, for example, there is a link between the reaction of the learner at each stage and the teacher's behaviour and his instructions, from the beginning to the end of the process, in negotiating the mistakes, and giving direct/indirect and metalinguistic feedback. Myles et al. (1998; 1999) have illustrated that varying strategies in SLA could be built one after another, in the same fashion as with the staged process in the IWP.

\subsection{The IWPApproach, Sociocultural Theory (SCT) and the Importance of Interaction}

One of the SLA theories on which the IWP is based is the Interactionist view, having in consideration that the IWP aims to facilitate the learning process by activating L2 learners' internal processes such as attention, noticing, and rehearsal which, in turn, makes the acquisition of the target linguistic data possible. To clarify the relationship between the IWP and Sociocultural Theory, Lantolf\& Thorne (2006) mention that "SCT has its origins in the writings of the Russian psychologist L.S. Vygotsky and his colleagues" (p. 197). They add that the most important forms of human cognitive activity develop through interaction. With regard to SLA, Sociocultural Theory believes learning is dialogically based which means that the acquisition of the language occurs in the processof interaction rather than as a result of the interaction. Based on this perspective, SLA cannot be treated as a purely individual-based process, but rather as one shared between the individual and other persons (teacher/learners and learners/learners).

In designing the IWP, the dialogic interaction between learners themselves and the teacher is basic in performing the writing task. Having that space for interaction can create a context in which learners can participate actively. This interaction can demonstrate for the teacher what the L2 learners can do and what they cannot do, this in turn, gives the opportunity to the teacher to allocate time and a suitable type of feedback to the learners.

Hulstijn (2006) and Ellis (2006) suggested that attention, consciousness and awareness play a role in the implicit learning process, and this argument, supported by (Dekeyser, 2003; Ellis, 1994; and Schmidt, 1994), this is also in line with the point of views of (Schmidt \&Frota, 1986;Alanen, 1995; Ellis, 1996;Ellis \& Sinclair, 1999;Ellis\& 
Schmidt, 1997;Grabe\&Stoller, 1997; Leow,1997; Miyke\& Friedman,1998; Rosa \& O' Neil,1999; Mackey, 2002)and Swain \&Lapkin, 2002), who examined cognitive processes in second language learning; their conclusion was also supported by (Gass\&Varonis, 1994; Robinson, 1995, 2001and 2003;Long, 1996;Gass, 1997;Mackey et al.2000, and Philip,2003). They all agree that attention and awareness in particular have been identified as two cognitive processes that mediate input and L2 development through interaction.

\subsection{A Coalition of Resources}

Autonomous Induction Theory (Carroll, 1999 and 2001) posits that, SLA is facilitated by a coalition of sources that create input to learning. As defined and explained by Herschensohn (2003, p. 26), this theory brings together spontaneous input and form-focused guidance as two complementary components of the learning process. Carroll $(1999,2001)$ argues that the proposed input of learning is not simply processing input but can be considered as a restructuring of interlanguage grammar due to parsing failure on the part of the learner. In other words, Carroll made a distinction between processing for parsing and processing for acquisition. She mentioned that when the parsers fail, the acquisitional mechanisms are triggered, and added that during successful parsing, rules are activated in each processor, and failure occurs when the rules are inadequate or missing.

Carroll (1999, p. 365) defines learning in the context of Autonomous Induction Theory as a process which takes place whenever a parse fails (which results from incomprehensible input) and thereby, the process of learning takes place at several levels of analysis such as acoustic-phonetic, phonological, morpho-syntactic and semantic. Similarly, Herschensohn (2000, p. 203) suggests that learners use a coalition of resources such as Universal Grammar, constrained hypothesis space, primary linguistic data, instruction and feedback. This coalition of resources is visible in the IWPapproach.

The interactional process, whether it is negotiated interaction, interactional feedback, noticing gaps in knowledge by learners as well as by the teacher, while speaking or while writing in general, can direct the learners' attention to many things which might have been stored in their memory (implicit knowledge) but that they have temporarily forgotten. The teacher's role is to activate this knowledge which can relate to lexical items, grammatical constructions, phrasal verbs, prepositions, collocations, and so on. Different types of interaction promote development and lead to an actual improvement in learners' knowledge in the long term.

\section{Conclusion}

The IWPapproachpresents an innovated method for teaching writing, based on the literature review on L2 writing and the background to revising and redrafting. Firstly, research on process writing during the 1980s and 1990s was presented with the stages of process writing, followed by research on process writing in the $21^{\text {st }}$ century. Research on drafting/ redrafting and think-aloud protocols was presented, followed by reflection and feedback, and the researcher presented the importance of explicit grammar learning/teaching and explicit feedback (metalinguistic feedback) which can be implemented in the classroom context in the form of error analysis and contrastive analysis. Finally, the IWP approachwas presented (including explicit grammar learning/teaching, feedback, negotiation and interaction) as a form of Form-Focused-Instruction which integrates a strong interactional component. This provides a rationale for the IWP and the CGLTA and how they can help improve the ALEs' written accuracy by transferring the SLA and Applied Linguistics theories into practice in the classroom context.

\section{References}

Alanen, R. (1995). Input enhancement and rule presentation in second language acquisition, in: R. Schmidt (ed.) Attention and Awareness in Foreign Language Learning and Teaching (Technical Report No. 9) Honolulu: University of Hawai'i, Second Language Teaching and Curriculum Centre, 259-302.

Anderson, J. R. (1995). Learning and memory: an integrated approach. New York: John Wiley.

Atwell, N. (1987). In the middle. Portsmouth, NH: Heinmann.PMCid:2498478

Bitchener, J. (2005). The extent to which classroom teaching options and independent learning activities can help L2 writers improve the accuracy of their writing, In: Anderson, H. et al. (eds). Proceedings of the 2nd Independent Learning Association Oceania Conference. Auckland: Manukau Institute of Technology, pp: 1-7.

Bitchener, J., S. Young, \& D. Cameron, (2005).The effect of different type of corrective feedback on ESL student writing.Journal of Second Language Writing. 14: 33-41.http://dx.doi.org/10.1016/j.jslw.2005.08.001

Carroll, S. (1999). Putting 'input' in its proper place. Second Language Research, 15: 337-88.http://dx.doi.org/10.1191/026765899674928444 
Carroll, S. (2001). Input and Evidence: The Raw Material of Second Language Acquisition. Amsterdam-Philadelphia: John Benjamin. http://dx.doi.org/10.1016/j.jslw.2005.08.001

Cook, V. J. (2001). Second Language Acquisition. Oxford: Oxford University Press.

DeKeyser, R. (1998). Beyond focus on form: cognitive perspectives on learning and practising second language grammar, In: C. Doughty, \& Williams, J. (eds.). Focus on Form in Second Language Acquisition. Cambridge: Cambridge University Press, pp: 42-63.

DeKeyser, R. (2003). Implicit and explicit learning, In: C. J. Doughty \& Long, M. H. (eds): Handbook of Second Language Learning. Oxford: Blackwell, pp: 313-347.http://dx.doi.org/10.1002/9780470756492.ch11

Ellis, N. C. (ed.). (1994). Implicit and Explicit Learning of Languages.London: Academic Press-Harcourt Brace and Co. http://dx.doi.org/10.1002/9780470756492.ch11

Ellis, N. C. \& R. Schmidt (1997). Morphology and longer distance dependencies: Laboratory research illuminating the A in SLA, Studies in Second Language Acquisition. 19: 145-71.

Ellis, N. C. \& S. Sinclair (1996). Working memory in the acquisition of syntax: Putting language in good order, The Quarterly Journal of Experimental Psychology. 49A/1: 234-50.

Ellis, R. (1986). Classroom second Language Development. Oxford: Pergamon.

Ellis, R. (2006). Current issues in the teaching of grammar: as SLA Perspective, TESOLQuarterly, 40/1: 83-107.http://dx.doi.org/10.2307/40264512

Ellis, R. (2009). Corrective Feedback and Teacher Development, L2 Journal, 1: 3-18.

Ellis, R., Y. Sheen, M. Murakami, \& H. Takashima (2009). The effects of focused and focused written corrective feedback in English as a foreign language context. System 36: 353-371.http://dx.doi.org/10.1016/j.system.2008.02.001

Ellis, R., S. Loewen, S. Elder, R. Erlam, J. Philip \& H. Reinders (2008).Implicit and Explicit Knowledge in Second Language Learning, Testing and Teaching, Library of Congress Cataloging in Publication Data.http://dx.doi.org/10.1016/j.system.2008.02.001

Feez, S. C. (1998). Text-based Syllabus Design. Sydney: NCELTR, Macquarie University.

Ferris, D. R. (2002).Treatment of Error in Second Language Student Writing.Ann Arbour: University of Michigan Press.

Ferris, D. R. (2003).Response to student writing: implications for second language student. Ann Arbour: University of Michigan Press.

Ferris, D. R. (2004). The "Grammar Correction" debate in L2 writing: Where are we, and where do we go from here? (and what do we do in the meantime....?). Journal of Second Language Writing,13, pp: 49-62.http://dx.doi.org/10.1016/j.jslw.2004.04.005

Ferris, D. R. (2006). Does error feedback help student writers? New evidence on the short-and long-term effects of written error correction. In K. Hyland \& F. Hyland (eds.) 81-104.http://dx.doi.org/10.1016/j.jslw.2004.04.005

Fotos, S. (1993). Consciousness raising and noticing through focus on form: grammar task performance versus formal instruction. Applied Linguistics, 14/4:126-41.http://dx.doi.org/10.1093/applin/14.4.385

Fotos, S. \& R. Ellis (1991). Communication about grammar - a task based approach. TESOL Quarterly, 25/4: 605-28.http://dx.doi.org/10.2307/3587079

Fotos, S. \& H. Nassaji (eds.). (2007). Form-focused instruction and teacher education: Studies in honor of Rod Ellis. Oxford: Oxford University Press.PMid:17591034

Gass, S. (1997). Input, Interaction, and the Second Language Learner.Mahwah. NJ: Lawrence Erlbaum Associates.

Gass, M. \&Selinker, L. (2008).Second language Acquisition.An Introductory Course.Third edition. Mahwah, N.J.: Lawrence Erlbaum Associates.

Grabe, W. and F. Stoller, (1997). Reading and vocabulary development in a second language: A case study, in: J. Coady and T. Huckin (eds) Second Language Vocabulary Instruction: A Rationale for Pedagogy. Cambridge: Cambridge University Press, 98-122.

Gass, S. and E. Varonis, (1994). Input, interaction, and second language production, Studies in Second Language Acquisition 16: 283-302.http://dx.doi.org/10.1017/S0272263100013097 
Harmer, J. (1991).The Practice of English Language Teaching. London: Longman. http://dx.doi.org/10.1017/S0272263100013097

Hedge, T. (2003). Teaching and Learning in the Language Classroom. Oxford: Oxford University Press.PMCid: 1502608

Hendrickson, J. (1987). Error correction in foreign language teaching: Recent theory, research and practice. Modern Language Journal.62: 387-398.

Herschensohn, J. (2000). The Second Time Around: Minimalism and L2 acquisition. Amsterdam Philadelphia: Benjamins.

Herschensohn, J. (2003). Missing inflection in second language French: accidental infinitives and other verbal deficits.Second Language Research. 17: 273-305.http://dx.doi.org/10.1191/026765801680191514

Hulstijn, J. H., (2006). Theoretical and empirical issues in the study of implicit and explicit second -language learning. Studies in Second Language Acquisition. 27: 129-140. http://dx.doi.org/10.1191/026765801680191514

Hyland, K. \& F. Hyland, (2006). Feedback in second language writing: Contexts and issues. Cambridge: Cambridge University Press.http://dx.doi.org/10.1017/CBO9781139524742

Krashen, S. (1982).Principles and Practice in Second Language Acquisition. Oxford: Pergamon. http://dx.doi.org/10.1017/CBO9781139524742

Lantolf, J. \& S. Thorne, (2006). Sociocultural theory \& the genesis of 2nd language development.Oxford: Oxford University Press.

Leow, R. P. (1997). Attention, awareness, and foreign language behaviour. Language Learning.47: 467-505.http://dx.doi.org/10.1111/0023-8333.00017

Leow, R. (2001). Do learners notice enhanced forms while interacting with the L2? An online and offline study of the role of written input enhancement in L2 reading.Hispania, 84/1: 496-509.http://dx.doi.org/10.2307/3657810 Lightbown, P. \&Spada, N. (2006).How Languages are Learned. Second edition Oxford: Oxford University Press. http://dx.doi.org/10.1111/0023-8333.00017

Long, M. (1996). The role of the linguistic environment in second language acquisition. In: W. C. Ritchie \& Bhatia, T. K. (eds): Handbook of Second Language Acquisition. New York: Academic Press, pp: 413-68.

Lyster, R. (2004).Differential effects of prompts and recasts in form-focused instruction.Studies in Second Language Acquisition. 26: 399-432.http://dx.doi.org/10.1017/S0272263104263021

Mackey, A. (2002). Beyond production: Learners' perceptions about interactional processes, International Journal of Educational Research. 37: 379-94.http://dx.doi.org/10.1016/S0883-0355(03)00011-9

Mackey, A., S. Gass, and K. McDonough, (2000). How do learners perceive implicit negative feedback? Studies in Second Language Acquisition. 22: 471-97.http://dx.doi.org/10.1017/S0272263100004022

Miyake, A. and N. F. Friedman, (1998). Individual differences in second language proficiency: Working memory as "language aptitude". in A. E. Healy and L. E. Bourne (eds): Foreign Language Learning: Psycholinguistic studies on training and retention. Mahwah, NJ: Erlbaum, 339-64. http://dx.doi.org/10.1017/S0272263104263021

Mourssi, A. M. (2006). The role of motivation and learning strategies in improving second language learners' writing. M.A. dissertation submitted to the University of Birmingham.

Myles, F., J. Hooper, \& R. Mitchell (1998).Rote or rule?Exploring the role of formulaic language in classroom foreign language learning.Language Learning. 48: 323-63.http://dx.doi.org/10.1111/0023-8333.00045

Myles, F., R. Mitchell, \& J. Hooper (1999). Interrogative chunks in French L2: A basis for creative construction? Studies in Second Language Acquisition. 21: 49-80. http://dx.doi.org/10.1111/0023-8333.00045

Norris, J. \& L. Ortega. (2001). Does type of instruction make a difference? Substantive findings from a meta-analytic review. Language Learning 51/ Supplement, 1:157-213.

Nunan, D. (2009). Task-based Language Teaching. Cambridge: Cambridge University Press.PMCid:2628561

Pennington, M. C., Brock, M. N. \&Yue, F. (1996). Explaining How (Hong?) Kong Students' response to process writing: An exploration of causes and outcomes. Journal of Second Language Writing.5, pp: 227-252.http://dx.doi.org/10.1016/S1060-3743(96)90003-X

Philip, J. (2003). Constraints on "noticing the gap": Nonnative speakers' noticing of recasts in NS-NNS interaction. Studies in Second Language Acquisition. 25: 99-126. http://dx.doi.org/10.1016/S1060-3743(96)90003-X 
Pica, T. (2008). Task-based Instruction, In: N. Van Deusen School \&Harnberger, N. H. (eds.) Encyclopedia of Language and Education. New York: Springer Science/Business Media LLC, pp: 71-82.

Pienemann, M., (2005).Cross-linguistic Aspects of Processability Theory. Amsterdam: Benjamins.

Richards, J., Platt, J. \& H. Weber, H. (1999). Longman Dictionary of Language and Applied Linguistics.(18th ed.). Harlow: Longman Group UK.

Richards, J. \&Redgers, T. (2006).Approaches and Methods in Language Teaching.Cambridge: Cambridge University Press.

Rivers, W. (1987).Interactive Language Teaching. 1st edition. Cambridge: Cambridge University Press.

Robinson, P. (1995). Review article: Attention, memory and the "noticing" hypothesis, Language Learning.45: 283-331.http://dx.doi.org/10.1111/j.1467-1770.1995.tb00441.x

Robinson, P. (2001). Individual differences, cognitive abilities, aptitude complexes and learning conditions in second language acquisition.Second Language Research. 17: 368-92.http://dx.doi.org/10.1191/026765801681495877

Robinson, P. (2003). Attention and memory during SLA. in: C. Doughty and M. Long (eds.) (2003). Handbook of Second Language Acquisition.Oxford: Blackwell, 631-78.http://dx.doi.org/10.1111/j.1467-1770.1995.tb00441.x

Rosa, E. and M. O'Neill, (1999). Explicitness, intake, and the issue of awareness: Another piece to the puzzle. Studies in Second Language Acquisition. 21: 511-56.http://dx.doi.org/10.1017/S0272263199004015

Schmidt, R. (1994). Implicit learning and the cognitive unconscious: Of artificial grammar and SLA. in: N. Ellis (ed.): Implicit and Explicit Learning of Languages. San Diego: Academic Press, 165-210. http://dx.doi.org/10.1017/S0272263199004015

Schmidt, R. and S. Frota, (1986). Developing basic conversational ability in a second language: A case study of an adult learner of Portuguese, in: R. Day (ed.): Talking to learn: Conversation in second language acquisition. Rowley, MA: Newbury House, 237-326.PMid:3487613

Sheen, Y. (2007). The effect of focused written corrective feedback and language aptitude on ESL learners' acquisition of articles.TESOL Quarterly. 4: 255-283.

Swain, M. and S. Lapkin, (2002). Problems in output and the cognitive processes they generate: A step towards second language learning. Applied Linguistics. 16: 370-391.

Swain, M. (1985). Communicative Competence: some roles of comprehensible input and comprehensible output in its development. In: S.M. Gass, \& Madden, C. G. (eds.) Input in Second Language Acquisition. Rowley, MA: Newbury House, pp: 235-253.

Truscott, J. (1996). The case against grammar correction in L2 writing classes.Language Learning. 46, pp: 327-369.http://dx.doi.org/10.1111/j.1467-1770.1996.tb01238.x

Truscott, J. (1999). The case for "The case for grammar correction in L2 writing classes": A response for Ferris. Journal of Second Language Writing. 8, pp: 111-122.http://dx.doi.org/10.1016/S1060-3743(99)80124-6

Truscott, J. (2007). The effect of error correction on learners' ability to write accurately.Journal of Second Language Writing.16, pp: 255-272.http://dx.doi.org/10.1016/j.jslw.2007.06.003

Ur, P. (1996). A course in language teaching. Cambridge: Cambridge University Press. http://dx.doi.org/10.1111/j.1467-1770.1996.tb01238.x

VanPatten, B. (1992). Second-language acquisition research and foreign language teaching.Part 2. ADFL Bulletin 23: 23-27.

VanPatten, B. (2003). From input to output: A teacher's guide to second language acquisition. Mahwah, MJ: Erlbaum. 
Table 1. The Roles of the Teacher and the Roles of the Learners in the IWP Approach

\begin{tabular}{|c|c|}
\hline Teacher's Role in IWP & Students' Role in IWP \\
\hline Getting the SS motivated to the task & $\begin{array}{l}\text { SS get ready for the picture-story writing task, } \\
\text { receive the question paper and think individually } \\
\text { about how to perform the task, listen to the } \\
\text { teacher's instructions, brainstorm and get ready to } \\
\text { participate effectively in performing the task and } \\
\text { ask questions based on the pictures }\end{array}$ \\
\hline $\begin{array}{l}\text { Teacher answers all students' questions related to } \\
\text { the story in turn }\end{array}$ & $\begin{array}{l}\text { SS write one or two verbs under each picture to } \\
\text { be used expressing the events of the story, (in the } \\
\text { simple past form) and define the subject }\end{array}$ \\
\hline $\begin{array}{l}\text { Teacher elicits and writes down students' } \\
\text { mistakes while talking about the picture-story }\end{array}$ & $\begin{array}{l}\text { SS ask questions related to the verbs used and } \\
\text { the new vocabulary used in their writing }\end{array}$ \\
\hline $\begin{array}{l}\text { Teacher explains the students' mistakes following } \\
\text { Grammar Translation Method, showing the } \\
\text { differences between English and Arabic sentences } \\
\text { (as an oral feedback on students' mistakes while } \\
\text { speaking about the picture-story) }\end{array}$ & $\begin{array}{l}\text { SS take notes about the unclear points; arrange } \\
\text { their ideas and the sequence of the story events }\end{array}$ \\
\hline $\begin{array}{l}\text { Teacher asks students to revise and redraft their } \\
\text { speaking based on target-like forms of the simple } \\
\text { past tense and on the target-like forms of the } \\
\text { English sentence which is different from the } \\
\text { Arabic form }\end{array}$ & $\begin{array}{l}\text { SS notice their mistakes related to the simple } \\
\text { past form and the target-like structure of the } \\
\text { English sentences }\end{array}$ \\
\hline $\begin{array}{l}\text { Teacher asks students to speak about the } \\
\text { picture-story, revise and redraft their speaking } \\
\text { together in pairs or in groups }\end{array}$ & $\begin{array}{l}\text { SS revise and redraft their speaking after } \\
\text { correcting their mistakes based on feedback } \\
\text { received, and speak about the story }\end{array}$ \\
\hline $\begin{array}{l}\text { Teacher asks students to write the first written } \\
\text { draft and gives his/her written feedback for each } \\
\text { student }\end{array}$ & $\begin{array}{l}\text { SS speak about their story after revising and } \\
\text { drafting their story }\end{array}$ \\
\hline $\begin{array}{l}\text { Teacher analyses the students' errors following } \\
\text { the intensive interaction with the students } \\
\text { following communicative approach (after marking } \\
\text { the first draft) }\end{array}$ & $\begin{array}{l}\text { SS receive the teacher's written feedback and } \\
\text { rewrite after revising and correcting }\end{array}$ \\
\hline $\begin{array}{l}\text { Teacher holds individual discussions with weaker } \\
\text { students (whenever it is possible) }\end{array}$ & $\begin{array}{l}\text { SS interact with the teacher and ask for } \\
\text { clarification if they do not understand the } \\
\text { feedback given }\end{array}$ \\
\hline $\begin{array}{l}\text { Teacher asks students to write the final draft } \\
\text { individually and read their writing in front of the } \\
\text { class; then other students are asked to give their } \\
\text { feedback in a communicative way }\end{array}$ & Students write the final draft \\
\hline $\begin{array}{l}\text { Teacher gives the final grade for each student and } \\
\text { asks them to write down their weak points to be } \\
\text { considered in the following writing lesson }\end{array}$ & $\begin{array}{l}\text { SS read the final draft loudly at the front of the } \\
\text { class }\end{array}$ \\
\hline
\end{tabular}




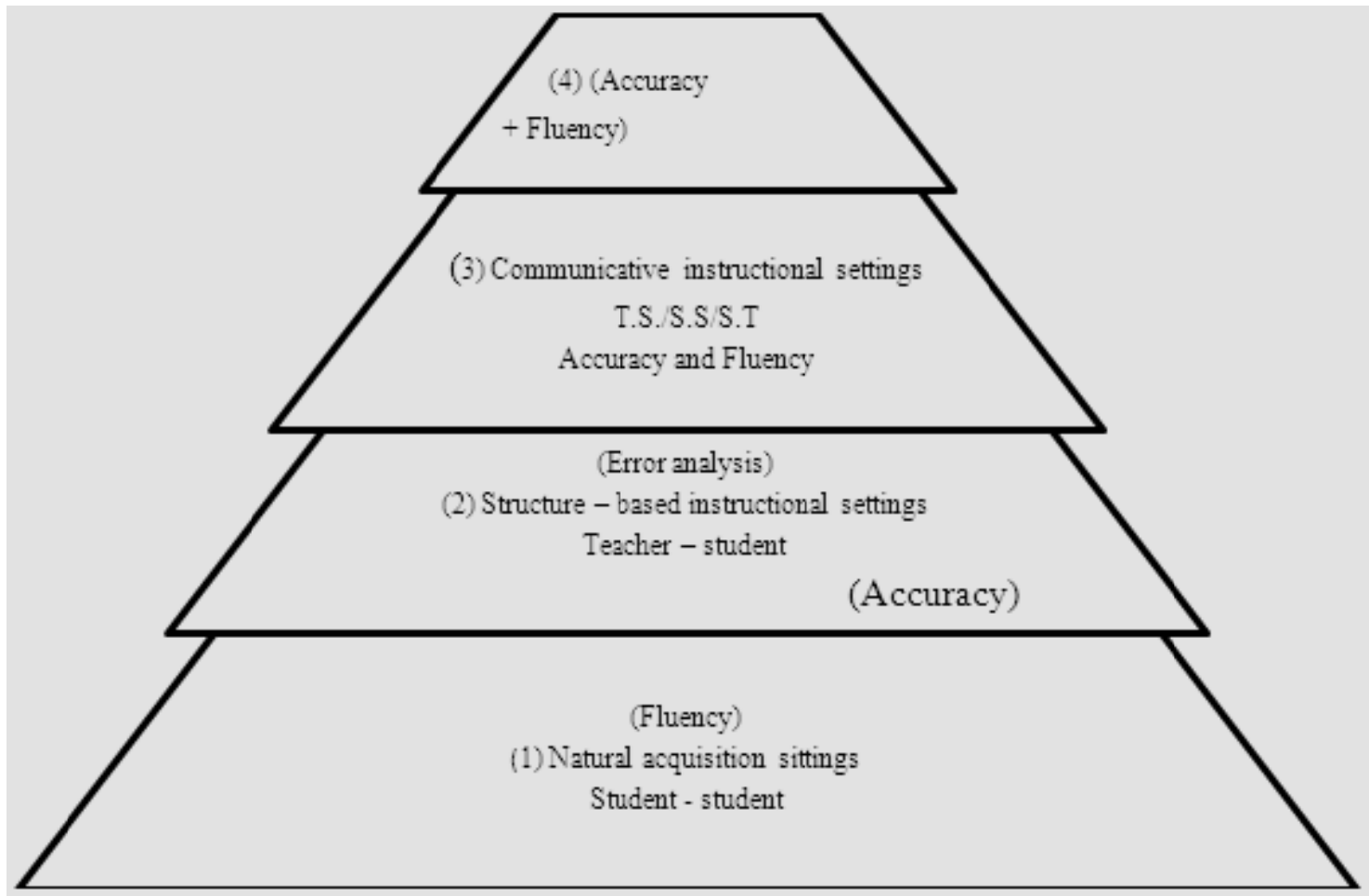

Figure 1. Learners' Different Settings in the IWP Approach

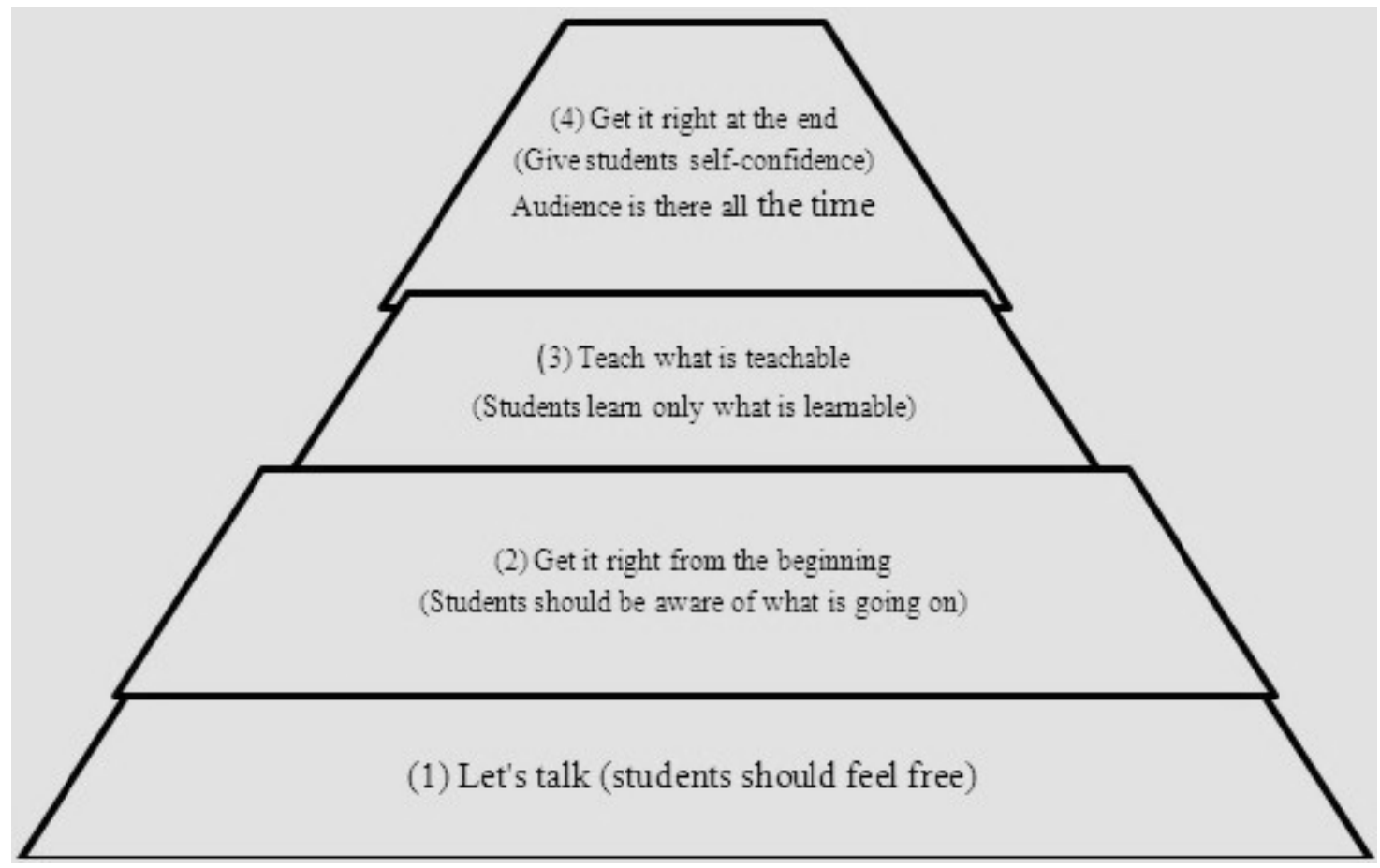

Figure 2. Theories of SLA and Proposals Implemented in the IWP 


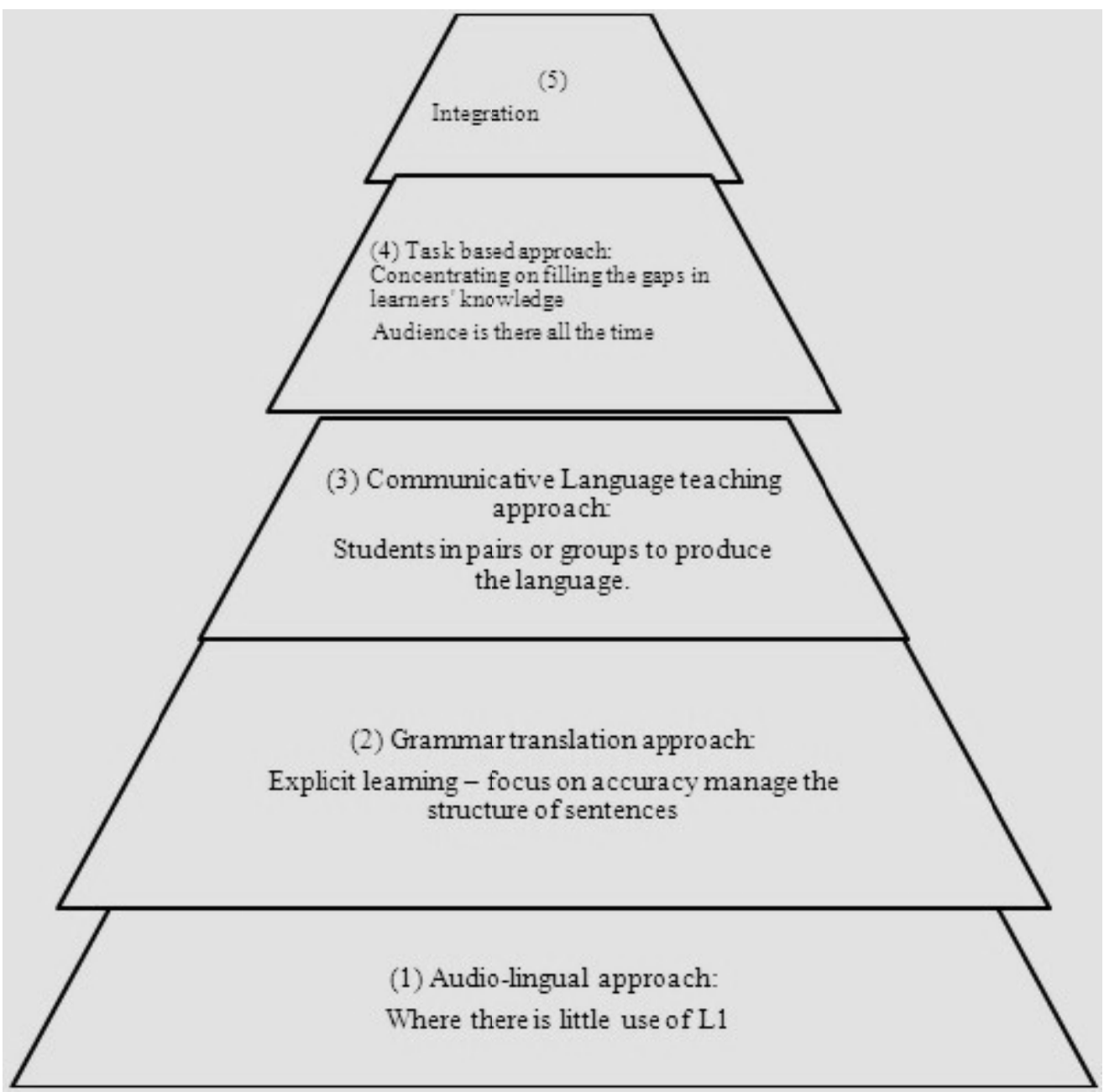

Figure 3. The ELT Methods and Approaches Followed in the IWP Approach 
Appendix (A)

Lesson Preparation Activity: Writing

Class: $12 / 2$

Date: $3^{\text {rd }}$ Jan. $-12^{\text {th }}$ May 2010

Picture- Story (1-8)

\begin{tabular}{|c|c|c|c|}
\hline Step & Learning Objectives and activities & Material & Time \\
\hline $1-\mathrm{T}$ & Getting the Ss motivated to the task. & & 5 mins \\
\hline $1-\mathrm{Ss}$ & $\begin{array}{l}\text { Ss get ready for the picture writing story task, receive the question paper and } \\
\text { think individually about how to perform the task, listen to the teacher's } \\
\text { instructions, brainstorming and get ready to participate effectively in performing } \\
\text { the task and ask questions based on the pictures. }\end{array}$ & & $10 \mathrm{mins}$ \\
\hline $2-\mathrm{T}$ & $\begin{array}{l}\text { Teacher answers the students questions related to the story in turn and covers all } \\
\text { the students' questions. }\end{array}$ & & \\
\hline $2-\mathrm{Ss}$ & $\begin{array}{l}\text { Ss write one or two verbs under each picture to be used expressing the events of } \\
\text { the story, (in the simple past / past cont form) and define the subject. }\end{array}$ & & 10 mins \\
\hline $3-\mathrm{T}$ & $\begin{array}{l}\text { Teacher elicits and writes down students mistakes while talking about the pictures } \\
\text { story }\end{array}$ & & $5 \mathrm{mins}$ \\
\hline 3 -Ss & $\begin{array}{l}\text { Ss ask questions related to the verbs will be used and the unknown vocabulary } \\
\text { might be used in their writing. }\end{array}$ & & $15 \mathrm{mins}$ \\
\hline $4-\mathrm{T}$ & $\begin{array}{l}\text { Teacher explains the students mistakes following Grammar Translation Method, } \\
\text { showing the differences between English and Arabic sentences (as an oral } \\
\text { feedback on students mistakes while speaking about the pictures story) }\end{array}$ & & $20 \mathrm{mins}$ \\
\hline $4-\mathrm{Ss}$ & $\begin{array}{l}\text { Ss take notes about the unclear points, arrange their ideas and the sequence of the } \\
\text { story events. }\end{array}$ & & $10 \mathrm{mins}$ \\
\hline $5-\mathrm{T}$ & $\begin{array}{l}\text { Teacher asks students to revise and redraft their speaking based on target-like } \\
\text { form of simple past tense/aspect as well as the target-like form of the English } \\
\text { sentence which is different from the Arabic form }\end{array}$ & & \\
\hline $5-\mathrm{Ss}$ & $\begin{array}{l}\text { Ss notice their mistakes related to the simple past form and the target-like } \\
\text { structure of the English sentences. }\end{array}$ & & 5 mins \\
\hline $6-\mathrm{T}$ & $\begin{array}{l}\text { Teacher asks students to speak about the pictures story revising and redrafting } \\
\text { their speaking together in pairs or in groups }\end{array}$ & & $20 \mathrm{mins}$ \\
\hline 6-Ss & $\begin{array}{l}\text { Ss revise and redraft their speaking after correcting their mistakes based on } \\
\text { feedback received and speak about the story }\end{array}$ & & $10 \mathrm{mins}$ \\
\hline $7-\mathrm{T}$ & $\begin{array}{l}\text { Teacher asks students to write the first written draft and target-like them giving } \\
\text { his written feedback for each student. }\end{array}$ & & \\
\hline 7-Ss & Students speak about their story after revising and drafting their speaking story. & & 20 mins \\
\hline
\end{tabular}

\begin{tabular}{|c|c|c|c|}
\hline Step & Learning Objectives and activities & Material & Time \\
\hline $8-\mathrm{T}$ & $\begin{array}{l}\text { Teacher analyses the students errors following the intensive interaction with the } \\
\text { students following communicative approach (after marking the first draft) }\end{array}$ & & 20 mins \\
\hline 8-Ss & $\begin{array}{l}\text { Students get the teachers written feedback and rewrite after revising and } \\
\text { correction. }\end{array}$ & & \multirow{4}{*}{$\begin{array}{l}00 \\
10 \mathrm{mins}\end{array}$} \\
\hline 9-T & Teacher holds individual conferences with weak students. & & \\
\hline 9-Ss & Students listen and ask if they do not understand & & \\
\hline $10-\mathrm{T}$ & $\begin{array}{l}\text { Teachers ask students to write the final draft individually and read their writing at } \\
\text { the front of the class. Then he asks other students to give their feedback in a } \\
\text { communicative way. }\end{array}$ & & \\
\hline $10-\mathrm{Ss}$ & Students write the final draft. & & \multirow[t]{2}{*}{20 mins } \\
\hline $11-\mathrm{T}$ & $\begin{array}{l}\text { Teacher gives the final grade for each student and asks them to write down their } \\
\text { weak points to be considered in the following writing lesson. }\end{array}$ & & \\
\hline $11-\mathrm{Ss}$ & Ss read the final draft loudly & & $30 \mathrm{mins}$ \\
\hline
\end{tabular}

